\title{
Use of Non-timber Forest Products of Plant Origin as Food and the Impact of Human Activities on Their Sustainability in the South West of the Central African Republic
}

\author{
Guy Gildas Sosthène Zima ${ }^{1, ~ *}$, Fidele Mialoundama ${ }^{2}$, Innocent Kossa ${ }^{3}$ \\ ${ }^{1}$ Faculty of Sciences, Department of Plant Biodiversity, University of Bangui, Bangui, Central African Republic \\ ${ }^{2}$ Faculty of Sciences, Doctoral Training in Natural Sciences Agronomy, Marien Ngouabi University, Brazzaville, Congo \\ ${ }^{3}$ Higher Institute of Rural Development (ISDR), University of Bangui, Bangui, Central African Republic
}

Email address:

guyzima@yahoo.fr (G. G. S. Zima)

${ }^{*}$ Corresponding author

\section{To cite this article:}

Guy Gildas Sosthène Zima, Fidele Mialoundama, Innocent Kossa. Use of Non-timber Forest Products of Plant Origin as Food and the Impact of Human Activities on Their Sustainability in the South West of the Central African Republic. American Journal of Plant Biology.

Vol. 4, No. 4, 2019, pp. 96-104. doi: 10.11648/j.ajpb.20190404.17

Received: March 18, 2019; Accepted: June 16, 2019; Published: October 31, 2019

\begin{abstract}
Non-timber forest products (NTFPs) play a very important role in the food and nutrition security of developing countries and constitute a rich heritage that must be explored and brought to a higher level. In view of this issue, a study was carried out in 09 villages in the intervention zone of the Kadéi Forestry Society located in the South West of the Central African Republic (CAR). This study aims to identify NTFPs of plant origin with high food potential and the impacts of human activities on their sustainability. On the basis of various methodological approaches (ethno botanical surveys of 516 households, literature review, inventory technique...), data were collected, processed and analysed. The results obtained made it possible to carry out an inventory of 69 non-timber plant species belonging to 25 families and 2 large systematic groups namely Gnetophytes and Magnoliophytes. The relative use of plant organs showed that fruits (47\%) are consumed more often followed by leaves (36\%). The variables collected from the types of uses made it possible to identify 9 priority NTFPs and to highlight the gradual disappearance of 6 large NTFPs due to the effects of human activities directly affecting the ecological niche and the sustainability of these natural resources. In such a context where NTFPs remain a livelihood, the rigorous implementation of good farming practices can contribute to their rational use and conservation for the benefit of future generations.
\end{abstract}

Keywords: NWFP Food Plant, Human Activities, Sustainability, Central African Republic

\section{Introduction}

In the tropical and subtropical forests of Africa, Asia and Latin America, the importance of non-timber forest products (NTFPs) is well established [1]. It is widely known that these products supplement household agricultural production by providing essential nutritional commodities, medicinal products, fodder, etc.

NTFPs for food or consumables of plant origin are vital biological resources for the people of the Central African Republic. They are used in various ways, as daily sources of vitamins, lipids (fats and oils), proteins and minerals [2].
These NTFPs play a very important socio-economic role in ensuring food security and improving household income [3]. About 72 percent of the Central African population is totally or partially dependent on it for their livelihood. Despite the availability and enormous potential for NTFPs, it's linked to the variability of the country's ecosystems, the NTFP subsector remains informal and marked by a very low capacity for valorising these products. On the systematic level, some NTFPs are well known and inventor while a good majority remains unknown. These NTFPs are under increasing anthropogenic pressure, leading to dysfunction of terrestrial ecosystems and loss of biodiversity [4]. The current anarchic rate of use of these natural resources by rural and urban 
populations is increasing faster than the pace of their renewal. The factors which explains this include, but are not limited to, overuse of fuel wood, logging, mining, bushfires, drought, overgrazing, expansion of agricultural land, infrastructure development, urbanization, armed conflict (case of CAR), etc.

The improvement of the situation mentioned above requires a large range of available scientific information on the use and impacts of human activities on the species providing these NTFPs which unfortunately is not the case in CAR. It therefore seemed wise for us to collect and analyse reliable data on non-timber food products of plant origin existing in the CAR; notably in the south-west of the country, and on the other hand to identify the threats to these resources in order to propose measures of good practices leading to sustainable management of these natural resources. The problem statement of this study is centred around a single question: what is the real impact of human activities on the availability of Non-timber forest products of plant origin used for food in the South West of the Central African Republic?

The objective of this study is to identify NTFPs of vegetal

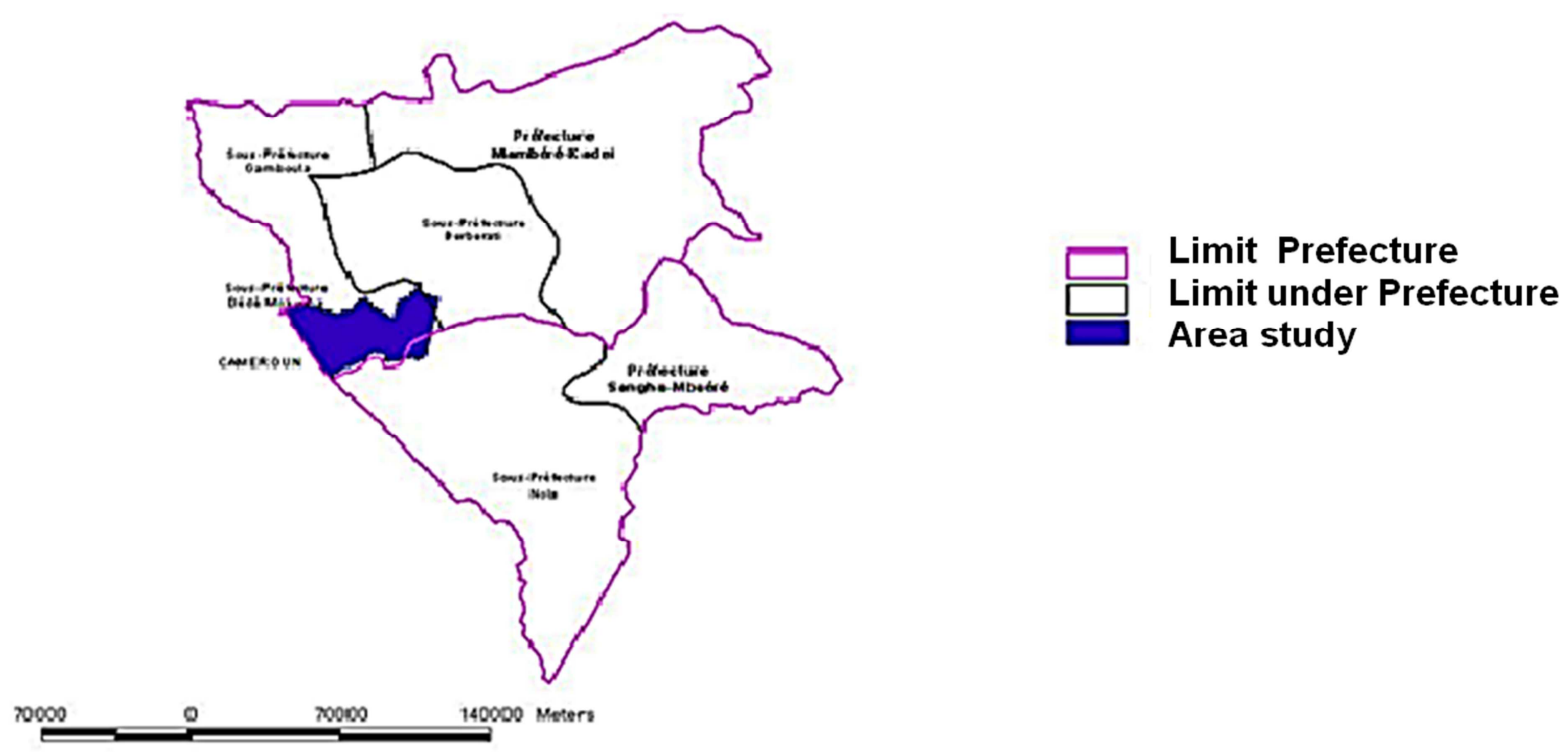

origin with high food potential and to evaluate the impacts of human activities on their sustainability. The hypothesis of this study is that "human activities contribute to the sustainable management of NTFPs of plant origin in the South West of the Central African Republic".

\section{Methodology}

\subsection{Study Area}

The study was carried out in the concession of the forest company of Kadéi (SFK). It operates under the Exploration and Development Permit 175 (PEA 175). The study area is geographically located between latitude $3^{\circ} 40^{\prime}$ and $4^{\circ} 04^{\prime}$ north and longitude $15^{\circ} 04^{\prime}$ and $15^{\circ} 32^{\prime}$ east. The PEA 175 is located in the south-western part of the Mambéré Kadei prefecture, specifically in the sub-prefectures of Sosso Nakombo and Dédé Mokouba. This prefecture covers about $30,150 \mathrm{~km}^{2}$ with a total population estimated at 76495 inhabitants (RGPH, 2010), an average density of 12.1 inhabitants per $\mathrm{km}^{2}$ and has about 75 villages.

Figure 1. Geographical location of the study area.

\subsection{Collection of Data}

It is based on two main aspects:

The first concerns literature review. In addition to identifying how previous work has addressed the issue of the use and impact of human activities on the sustainability of non-timber forest food products of plant origin in the Central African Republic, as well as elsewhere, but also to note the shortcomings.

The second component consisted of the collection of field data that took place during the period from September 2009 to February 2010 and their processing. A questionnaire designed according to the objectives of the study was then administered (semi-directive interview) to collect social, cultural and economic data from 516 households including 247 men and 269 women living in the nine (09) villages out of 75 that counts the PEA 175 of the SFK. These are Bamba, Djambala, M'bi, Binoumbi, Ngola, Djilo megombang, Yandoa, Gnemele and Bayanga ngombé. These villages represent the area with the highest production density of NTFPs where most of the Bantu and indigenous populations live $(29,486$ people: Bamba Town Hall, 2012). The Microsoft Excel software was used to tally the questionnaire and analyse the results on one hand; while the Cultural Relevance Index (CPI) was also used to help identify species with high utilization value. These stages made it possible to assess the different modes of harvesting and use of food NTFPs, as well as the ecological impacts on these biological resources. 


\subsection{Inventory of Non-timber Forest Products of Plant Origin}

The inventory technique used by [5]. was adopted during this work. It consisted of choosing plots with the help of the local community, and the criteria that allowed this choice were communicated to the local populations and authorities. The work consists in choosing plots accessible in the different places (aged secondary forest, young secondary forest, old fallow, young fallow, coffee plantation, swamp). Inventories of non-timber forest species (EFNL) are made by the plot method because they grow everywhere. The inventory system consisted of 14 plots with a surface area of $2500 \mathrm{~m}^{2}(50 \mathrm{~m} \times 50 \mathrm{~m})$, located in 7 types of land use (aged secondary forest, young secondary forest, partly undisturbed secondary forest, old fallow, young fallow, coffee plantation and swamp) representing the diversity of the ways of using the spaces identified within the region. The delimitation and the orientation of the plots were made by the technique of the compass. All food EFNLs with a diameter greater than $20 \mathrm{~cm}$ were measured using a measuring tape. For herbaceous and liana, their relative abundance was assessed using the semiquantitative scale of Braun Blanquet [6].

\section{Results}

\subsection{Systematic Groups of Inventory Non-timber Food Forest Species}

Food from NTFPs play a very important role in the survival of rural and urban populations. The inventory of food EFNL obtained in each of the 14 plots of $2500 \mathrm{~m}^{2}$ sampled in the study site (i.e. $3.5 \mathrm{ha}$ ) made it possible to identify 69 species belonging to 25 botanical families and to 2 major systematic groups, namely: Gnetophytes and Magnoliophytes. Gnetophyta have only one family: Gnetaceae, with only one genus Gnetum and Gnetum africanum. The group Magnoliophyta is the most important. Alone, it accounts for 68 species (99\%) spread over 24 families. The most represented families are: Arecaceae (6 species), Moraceae (4 species), Euphorbiaceae (3 species), Verbanaceae (3 species), Anacardiaceae (3 species),
Amaranthaceae (3 species), Rubiaceae (3 species), Sterculaceae (3 species), Clusiaceae ( 2 species).

Table 1. Inventory of major families of exploited food EFNLs.

\begin{tabular}{lllll}
\hline Systematic groups & Family's & $\mathbf{\%}$ & Species & $\mathbf{\%}$ \\
\hline Gnetophytes & 1 & 4 & 1 & 1 \\
Magnoliophytes & 24 & 96 & 68 & 99 \\
Monocotyledon & 9 & 36 & 16 & 23 \\
Dicotyledon & 15 & 60 & 52 & 76 \\
Total & 25 & 100 & 69 & 100 \\
\hline
\end{tabular}

\subsection{Morphological Forms of Food NTFPs}

The non-woody food forest species identified during this work are grouped into four (4) morphological types (Table 2 ). Trees $(50 \%)$ are the dominant morphological type, followed directly by herbaceous plants (21\%). The morphological types "lianas" and "shrubs" represent (10\%) and $(19 \%)$ respectively. These different morphological types offer different food from NTFPs exploited by households surveyed to varying degrees to meet domestic demand and/or commercial value of the product.

Table 2. Inventory of Morphological Types of Food NTFPs.

\begin{tabular}{lll}
\hline Morphological types & Number of Species & \% of Species \\
\hline Trees & 34 & 50 \\
Shrubs & 13 & 19 \\
Grass & 15 & 21 \\
Lianas (creeper) & 07 & 10 \\
Total & 69 & 100 \\
\hline
\end{tabular}

\subsection{Specific Wealth of Herbaceous Food EFNL}

To assess the species richness of herbaceous species providing NTFPs, we conducted a comprehensive floristic survey of all selected plots. Depending on the physiognomy of the vegetation, a coefficient of abundance-dominance was assigned to each species by the method of Braun Blanquet. Quantitative or abundance analyses require that recovery class values using this method be converted to quantitative units (Table 3 ). Table 3 below shows the recovery rate of herbaceous EFNL.

Table 3. Class of cover of herbaceous EFNL according to Braun Blanquet.

\begin{tabular}{ll}
\hline Coefficient of Abundance-Dominance & Meaning \\
\hline+ & Simply present, recovery and low abundance \\
1 & Abundant and weak or not very abundant covering with greater overlap \\
2 & Recovery rate of 5 to $25 \%$, very abundant species \\
3 & Recovery from $25 \%$ to $50 \%$, any abundance \\
4 & Recovery from $50 \%$ to $75 \%$, any abundance \\
5 & Recovery above $75 \%$, any abundance \\
\hline
\end{tabular}

At the end of this floristic survey, the results obtained show that herbaceous EFNL have a lower recovery rate in the study area. The coefficient 1 is significant relative to the other respective coefficients $+, 2,3,4$ and 5. It thus appears that the study area has a lot of herbaceous EFNL with a recovery rate of less than $5 \%$ and few EFNL with a recovery rate between 25 and $50 \%$. Indeed, $56.65 \%$ of species cover less than $5 \%$ of spaces. On the other hand, the least represented species (24.3\% in total) occupy between 25 and $75 \%$ of the forest areas. Species of classes $+, 1,2$ constitute weak colonies under forest and are therefore rare whereas those of other classes occupy strongly spaces, which makes them more accessible. 


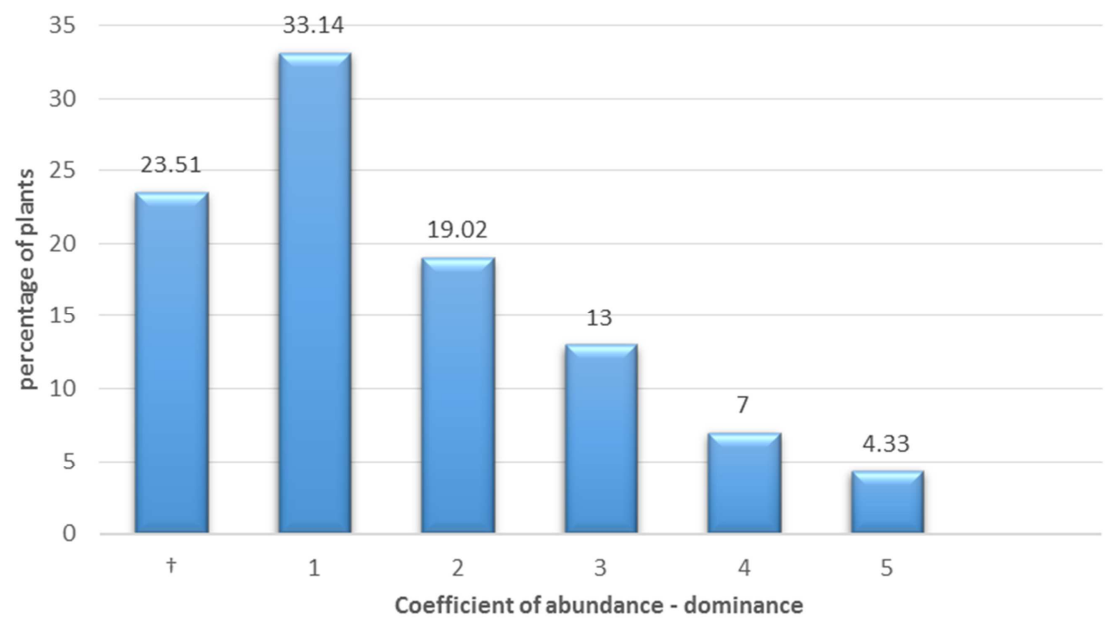

Figure 2. Recovery of herbaceous food EFNL.

\subsection{Classification of Non-timber Forest Products}

Several criteria for the classification of NTFPs have been proposed by FAO, CIFOR and CIRAD; but as part of this study, we opted for a classification based on usage or use. This classification is in line with the objectives set in this work. An inventory of the different plant species providing NTFPs has been completed. The use of these NTFPs varies from village to village or community to community. For example, for the same species, several different uses may be recorded depending on the community, region or village.

Table 4. List of EFNLs providing identified NTFPS.

\begin{tabular}{|c|c|c|c|c|c|}
\hline $\mathbf{N}^{\circ}$ & Scientific Name & Family's & Parts collected & Modes of use & Sampling technique \\
\hline 1 & Aframomum latifolium (Rose.) K. Shum & Zingiberaceae & Fruits & Edible & Picking \\
\hline 2 & Amaranthus spinosus L & Amaranthaceae & Leaves & Vegetables & Picking \\
\hline 3 & Ananas sativus L & Bromeliaceae & Fruits & Edible & Picking \\
\hline 4 & Anacardium occidentale L & Anacardiaceae & Fruits & Edible & Picking \\
\hline 5 & Annona senegalensis Pers & Anonaceae & Fruits & Edible & Picking \\
\hline 6 & Annonidium manii (Oliv.) Engl. et diel & Annonaceae & Fruits & Edible & Picking \\
\hline 7 & Artocarpus altilis (Parkinson) Foesberg & Moraceae & Fruits & Edible & Picking \\
\hline 8 & Borassus aethiopum Mart & Arecaceae & Fruits, Sap & Consumed, drinks & Picking \\
\hline 9 & Canarium schweinfurthii Eng & Burseraceae & Grains & Edible & Picking \\
\hline 10 & Carica papaya L & Caricaceae & Fruits & Edible & Picking \\
\hline 11 & Celosa argentea L & Amaranthaceae & Leaves & Vegetables & Picking \\
\hline 12 & Celosa trigyna $\mathrm{L}$ & Amaranthaceae & Leaves & Vegetables & Picking \\
\hline 13 & Citrus aurantifolia $\mathrm{L}$ & Rutaceae & Fruits & Edible & Picking \\
\hline 14 & Citrus sinensis L & Rutaceae & Fruits & Edible & Picking \\
\hline 15 & Citrus maxima L & Rutaceae & Fruits & Edible & Picking \\
\hline 16 & Coffea canephora & Rubiaceae & Fruits & Edible & Picking \\
\hline 17 & Cola acuminata P. Beauv Schott\&Endl & Sterculiaceae & Grains & Edible & Picking \\
\hline 18 & Cola urceolataK. Shum & Sterculiaceae & Grains & Edible & Picking \\
\hline 19 & Croton mubango Mull. Arg & Euphorbiaceae & Bark & Spices & Picking \\
\hline 20 & Cymbopogon citratus L. & Poaceae & Stubble & Herbal tea & Picking \\
\hline 21 & Dacryodes edulis (G. Don) H. J. Lam & Burseraceae & Fruits & Edible & Picking \\
\hline 22 & Dioscorea liebrechtsiana Benth & Dioscoreacae & Tubers & Edible & Picking \\
\hline 23 & Dorstenia psilumus Well & Moraceae & Leaves & Vegetables & Picking \\
\hline 24 & Elaeis guineensis Jacq & Arecaceae & Nuts, sap, bud & Edible, Drinks & Picking \\
\hline 25 & Garcinia Kola & Clusiaceae & Grains & Edible & Picking \\
\hline 26 & Gnetum africanum Welw & Gnetaceae & Leaves & Vegetables & Picking \\
\hline 27 & Hibiscus cannabinus L. & Malvaceae & Leaves & Vegetables & Picking \\
\hline 28 & Hilleria latifolia (Lam.) H. Walt. & Phytolacaceae & Leaves & Vegetables & Picking \\
\hline 29 & Ipomoea batatas Lam & Convolvulaceae & Leaves, Tubers & Vegetables, Consumed & Picking \\
\hline 30 & Irvingia gabonensis $\mathrm{L}$ & Irvingiaceae & Fruits, Almonds & Edible & Picking \\
\hline 31 & Landolphia owariensis P. Beauv & Apocynaceae & Fruits, Leaves & Edible & Picking \\
\hline 32 & Lantana camara L & Verbanaceae & Leaves & Herbal tea & Picking \\
\hline 33 & Lippia multiflora L & Verbanaceae & Leaves & Herbal tea & Picking \\
\hline 34 & Mammea africana (Oboto) & Clusiaceae & Fruits, & Edible & Picking \\
\hline 35 & Mangifera indica L & Anacardiaceae & Fruits & Edible & Picking \\
\hline 36 & Manihot esculenta Crantz & Euphorbiaceae & Leaves, Tubers & Edible & Picking \\
\hline 37 & Megaphrynium macrostachyum (K. Schum.), Milne & Marantaceae & Leaves & Packaging & Picking \\
\hline
\end{tabular}




\begin{tabular}{|c|c|c|c|c|c|}
\hline $\mathbf{N}^{\circ}$ & Scientific Name & Family's & Parts collected & Modes of use & Sampling technique \\
\hline & Redh & & & & \\
\hline 38 & Microdesmis puberula Hook. f. ex Planch & Pandaceae & Fruits, & Edible & Picking \\
\hline 39 & Monodora myristica (Gaertn.) Dunal & Annonaceae & Grains & Spices & Picking \\
\hline 40 & Morinda lucida Benth & Rubiaceae & Fruits & Edible & Picking \\
\hline 41 & Musa paradisiaca L & Musaceae & Fruits & Edible & Picking \\
\hline 42 & Musa acuminata & Musaceae & Fruits & Edible & Picking \\
\hline 43 & Myrianthus arboreus P. Beauv & Moraceae & Fruits, & Edible & Picking \\
\hline 44 & Olax gambecola Bail & Olacaceae & Fruits, Bark & Spices s & Picking \\
\hline 45 & Oncoba welwitschii Oliv & Flacourtiaceae & Leaves & Fermentation & Picking \\
\hline 46 & Pachira glabra Pasq & Bombacaceae & Grains & Edible & Picking \\
\hline 47 & Paullinia pinnata L & Sapindaceae & Fruits, & Edible & Picking \\
\hline 48 & Persea americana $\mathrm{L}$ & Lauraceae & Fruits & Edible & Picking \\
\hline 49 & Piper guineensis Schumach \& Thonn & Piperaceae & Fruits & Spices & Picking \\
\hline 50 & Pseudospondias microcarpa (A. Rich.) Engl & Anacardiaceae & Fruits & Edible & Picking \\
\hline 51 & Psidium guajava (DC.) & Myrtaceae & Fruits & Edible & Picking \\
\hline 52 & Pterocarpus soyauxii Taub & Papilionaceae & Grains & Edible & Picking \\
\hline 53 & Pycnanthus angolensis (Welw.) Warb. & Myristicaceae & Fruits & Edible & Picking \\
\hline 54 & Raphia hookeri G. Mann \& H. Wendl. & Arecaceae & Sap & Drinks & Picking \\
\hline 55 & Raphia sese De Wild & Arecaceae & Sap, Pulp & Drinks, Spices & Picking \\
\hline 56 & Raphia vinifera $L$ & Arecaceae & Sap & Drinks & Picking \\
\hline 57 & Ricinodendron heudelotii (Baill) Pierre ex Heckel & Euphorbiaceae & Grains & Spices & Picking \\
\hline 58 & Scorodophloeus zenkeri L & Caesalpiniaceae & Fruits & Edible & Picking \\
\hline 59 & Solanum nigrum $\mathrm{L}$ & Solanaceae & Leaves & Vegetables & Picking \\
\hline 60 & Syzygium guineensis (Wild) & Myrtaceae & Fruits & Edible & Picking \\
\hline 61 & Talinun triangulare $(\mathrm{Jacq}) \mathrm{W}$ & Portualceae & Leaves & Vegetables & Picking \\
\hline 62 & Tetrapleura Tetraptera (Schumach\&Tom) & Fabaceae & Leaves & Edible & Picking \\
\hline 63 & Theobroma cacao L & Sterculiaceae & Fruits & Edible & Picking \\
\hline 64 & Treculia africana Decne & Moraceae & grains & Edible & Picking \\
\hline 65 & Triumfetta cordifolia A. Rich & Sterculiaceae & Barks & Spices s & Picking \\
\hline 66 & Vernonia amygdalina Del & Asteraceae & Leaves & Vegetables & Picking \\
\hline 67 & Vitex madiansis Delile & Verbenaceae & Fruits & Edible & Picking \\
\hline 68 & Xanthosoma sagittifolium (L) & Araceae & Tubers & Edible & Picking \\
\hline 69 & Xylopia aetiopica (Dunal) & Annonaceae & Fruits & Spices s & Picking \\
\hline
\end{tabular}

\subsubsection{Parts and Organs Used as NTFPs Food}

Food from NTFPs of plant origin consist of leaves, young shoots, tubers, seeds and almonds, fruits, bark, pieces of wood, sap, etc. The relative use of plant organs in southwestern CAR shows that fruits (47\%) are widely consumed by the Central African population in general and in particular by the inhabitants of nine (09) villages surveyed, followed by leaves $(36 \%)$ that are used as vegetables in sauces. Tubers and/or rhizomes $(10 \%)$ are consumed as a staple and other organs such as bark (4\%) and small pieces of wood $(2 \%)$ are traditionally used as seasoning.

\subsubsection{Priority NTFPs Food}

The prioritization was done on the basis of the scores method. The score represents the ethno botanical value of use to assess the importance of the species at the food level. The variables collected according to the types of uses of the species make it possible to classify them according to a score ranging from 1 to 5 points ( 5 for the most popular species, 4 for the next, and so on...).

From the results obtained in the field, EFNL prioritization sheets producing food from NTFPs have been established. It is important to emphasize that an EFNL is said to be a priority if from a food, medical, commercial or other point of view, it presents various significant interests for a given population. The prioritization sheets were developed taking into account the socio-economic, environmental and cultural criteria of each EFNL. The table below presents the nine food from NTFPs identified.

Table 5. Lists of EFNLs Providing Priority NTFPs in South-West CAR.

\begin{tabular}{lllll}
\hline $\mathbf{N}^{\circ}$ & Scientific Name & Vernacular name & Family & Habitats \\
\hline 01 & Gnetum africanum & Koko & Gnetaceae & Forest \\
02 & Dostenia psilumus & Ngbein & Rubiaceae & Forest \\
03 & Raphia vinifera & Péké & Arecaceae & Swamp \\
04 & Elais guinenses & Mbourou & Arecaceae & Forest / Savana \\
05 & Irvingia gabonensis & Pays & Irvegiaceae & Forest \\
06 & Xylopia aetiopica & Mazindi & Anonaceae & Tree \\
07 & Dioscorea liebrechtsiana & Ngoui & Dioscoreaceae & Tree \\
08 & Afrotyrax lépido & Yembé & Styracacée & Forest \\
09 & Cola ssp. & Goro & Sterculaceae & Forest \\
\hline
\end{tabular}


Table 5. Continued.

\begin{tabular}{lllll}
\hline $\mathbf{N}^{\circ}$ & Parts used & Characteristic uses & Period (availability) & Score (Priority) \\
\hline 01 & Leaves & Vegetable & Permanent & 5 \\
02 & Leaves & Vegetable & Permanent & 5 \\
03 & Sap & Drinks & Permanent & 5 \\
04 & Sap & Drinks & Permanent & 5 \\
05 & Fruit & consumption & June-Oct & 4 \\
06 & Fruits & Spep-Dec & 4 \\
07 & Tubers & Consumption & Permanent & 4 \\
08 & Fruits, bark & Spices s & April-July & 4 \\
09 & Fruits & Aphrodisiac appetizer & Permanent & 4 \\
\hline
\end{tabular}

NB: Score 5: 1st priority; score 4: 2nd priority; score 3: 3rd priority.

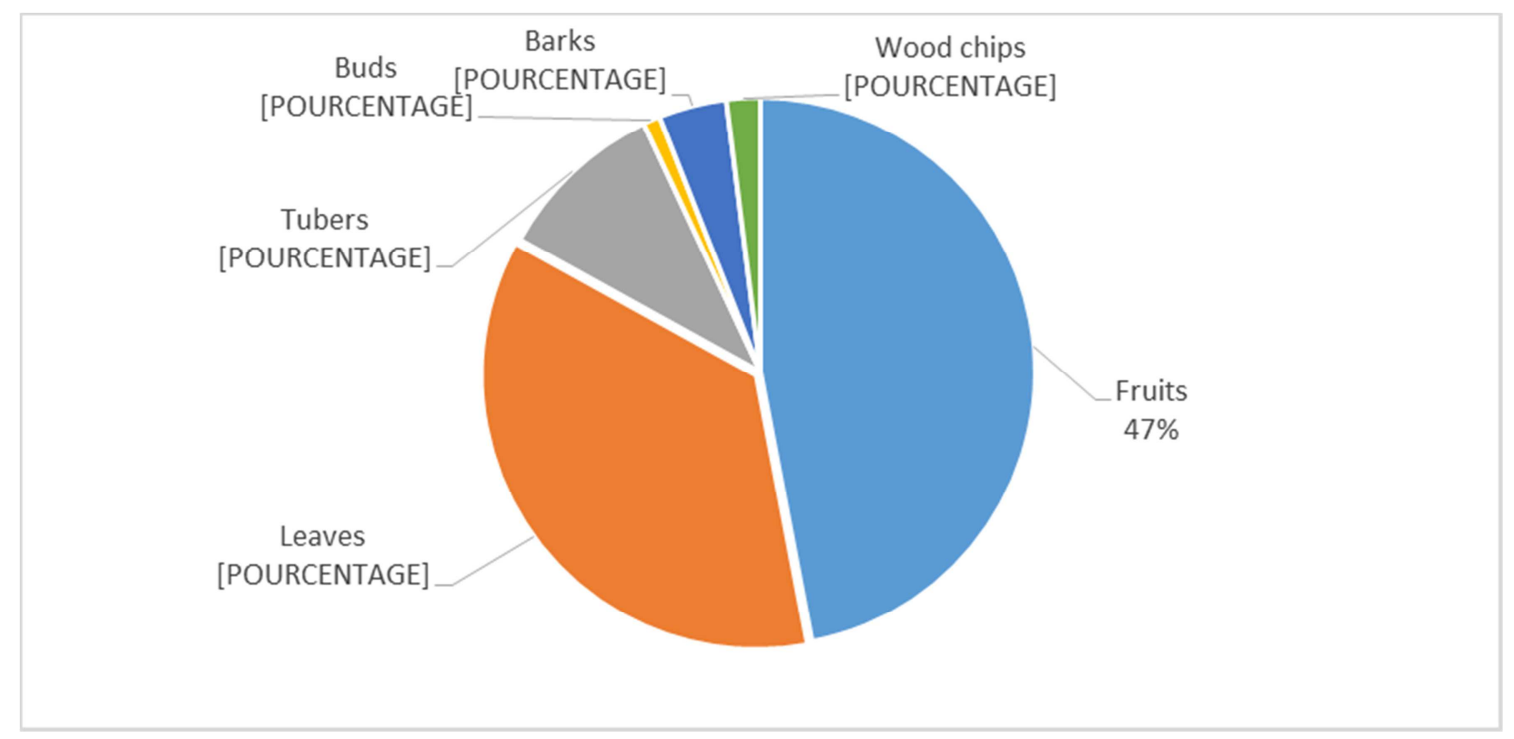

Figure 3. Proportion of different parts used as NTFPs food.

\subsection{Impact of Human Activities on Priority Food NTFPs}

The quantitative and qualitative analyses of the different EFNLs and their daily contribution to the life of the local populations show that all these species do not undergo the same anthropic pressure.

The data collected at the household level concerning the exploitation of NTFPs during this study enabled us to note the progressive disappearance of some priority non-timber forest species (Table 6) whose values obtained between $68 \%$ and $97 \%$. This degradation is linked to the excessive exploitation of these species by households because of their nutritional and nutritional value.

Table 6. List of food EFNLs in danger of extinction.

\begin{tabular}{|c|c|c|c|c|c|c|c|}
\hline $\mathbf{N}^{\circ}$ & Scientific Name & Vernacular name & Family & Habitat & Percentage & Score & Identified problems \\
\hline 01 & Raphia sp & Péké & Arecaceae & Swamp & 93,36 & 5 & Exploitation abusive \\
\hline 02 & Elais guinensis & Mbourou & Arecaceae & Forest/Savana & 89,17 & 5 & Exploitation abusive \\
\hline 03 & Dostenia psilumus, & Ngbein & Rubiaceae & Forest & 90.06 & 5 & Exploitation abusive \\
\hline 05 & Cola spp & Goro & Annonaceae & Forest/ Savana & 68.13 & 4 & Exploitation abusive \\
\hline 06 & Megaphrynium ssp & Kougbé & Marantaceae & Gallery / Forest & 68.09 & 4 & Exploitation abusive \\
\hline
\end{tabular}

NB: 5: 1st priority; 4: 2nd priority; 3: 3rd priority.

Impacts of Human Activities on How NTFPs Are Exploited

Non-timber food forest species are in high demand, given the NTFPs they produce daily. They are the subject of many threats impacting their sustainability. Several anthropogenic activities severely affecting the sustainability (survival) of these species within their ecological niches were identified during this study. These are techniques for harvesting NTFPs (fruits, leaves, bark, roots, exudates, stems, etc.) by local communities, logging techniques and peasant practices. In order to measure the pejorative effects of these practices on natural resources, we used the impact evaluation parameters used by [25] to assess (i) the quantity of product to be exploited, (ii) the harvesting technique of the harvested organ, and (iii) the sampling frequency.

1. The Leaves.

Various techniques are used by local communities to obtain leaves of NTFP species. Impacts on the resource often vary by species. 
Table 7. Impact of leaf exploitation on the resource according to the biological type.

\begin{tabular}{lllll}
\hline Biological types & Harvest Method & Period & Impact on the resource & Identified species \\
\hline Shrub/small Tree/young tree & Standing tree & Permanent & +++ & Dostenia psilumus \\
Grass & Standing tree & Permanent & +++++ & Megaphrynium macrostachyum Piper umbellatum \\
Lianas (creeper) & Standing tree & Permanent & +++++ & Gnetum africanum, Piper guineensis \\
\hline
\end{tabular}

N. B: +: very weak; ++: weak; +++: strong; ++++: very strong.

2. The fruits.

Fruit exploitation of shrubs or productive young trees for self-consumption causes little damage to the forest structure. The treetops of these trees being easily accessible, the fruits are harvested either by climbing on the tree or with the help of a pole. When the tree has become too big and is no longer accessible to harvesters, two options are used by the populations of the areas surveyed:

Those who wait for the fruits to fall $(41 \%$ of households surveyed);

Those who fell the tree to easily harvest the fruits (59\% of households especially traders)

The second method has a detrimental effect on the life cycle of the tree and unfortunately adopted for producing trees whose fruits quickly decline, with simultaneous physiological (and commercial) maturation and massive: this is the case of Annonidium mannii observed in the field as part of this study.

Table 8. Impact of fruit exploitation on the resource according to the biological type.

\begin{tabular}{llllll}
\hline Parts used & Biological types & Harvest Method & Period & $\begin{array}{l}\text { Impact on } \\
\text { the resource }\end{array}$ & Identified species \\
\hline $\begin{array}{l}\text { Pulp/almond } \\
\text { Almond }\end{array}$ & $\begin{array}{l}\text { Shrub/small Tree/young tree } \\
\text { Tree/big Tree }\end{array}$ & $\begin{array}{l}\text { Standing tree or uprooted tree } \\
\text { Total or partial collection of fruits }\end{array}$ & $\begin{array}{l}\text { Seasonal } \\
\text { Seasonal }\end{array}$ & ++++ & Garcina lucida; Penianthus longifolius \\
Pulp & Tree/big Tree & $\begin{array}{l}\text { Standing tree or after felling of the } \\
\text { tree après Felling }\end{array}$ & Seasonal & ++++ & Ricinodendron heudelotii \\
\hline
\end{tabular}

N. B: +: very weak; ++: weak; +++: strong; +++++: very strong.

\section{Bark, Roots, Tubers and Stems}

These different parts of NWFP are used in most of the surveyed area as spices (Condiments). The removal of barks and stems leaves high impacts which is observable on the ground. Depending on the biological type, the tuber harvested is sometimes high, meanwhile it is not important for the roots. It is important to note that the populations should be sensitized against debarking because the tracing around the tree trunk is a practice of unsustainable exploitation of the resources.

Table 9. Impact of bark, root and stem harvest on the resource according to the biological type.

\begin{tabular}{llllll}
\hline Parts used & Biological types & Harvest Method & Period & \multicolumn{2}{c}{$\begin{array}{l}\text { Impact on the } \\
\text { resource }\end{array}$} \\
\hline Bark & Shrub/small tree/Tree /Big tree & Standing tree or after felling & Permanent & +++++ & Garcina lucida \\
Roots & Shrub/small tree & After felling the tree & Permanent & +++++ & Penianthus longifolius Garcina lucida \\
Tuber & Lianas (creeper) & Removal & Permanent & ++++ & Dioscorea liebrechtsiana \\
Stem & Shrub/petit Tree/Tree & Felling & Permanent & +++++ & Xylopia aethiopica, Paulinia pinnata \\
Sap & Standing tree or Felling & Standing tree or Felling & Permanent & +++++ & Raphia ssp Elais guinenses \\
\hline
\end{tabular}

N. B: +: very weak; ++: weak; +++: strong; ++++: very strong.

\section{Discussion}

Forest species providing food from NWFPs are the most exploited by the populations in the study area. Their use varies from one village to another or from one community to another. Edible fruits (47\%) represent the most consumed portion of food from NWFP which are raw or fresh, such as Landolphia owariensis, Cola acuminata and Coula edulis. The seeds of Cola acuminata and Garcinia kola are especially popular with men because of their aphrodisiac and stimulating properties. These fruits provide food spices that can be eaten because of their spicy taste or used for seasoning dishes, such as Xylopia aethiopica and Monodora angolensis; Adansonia digitata, Croton mubango, Scorodophloeus zenkeri and Piper guineense. [7]. showed in his study on "Strengthening food security in Central Africa through the management and sustainable use of non-timber forest products" that fruits $(45 \%$ edible organs $)$ are commonly sought and consumed by the Congolese population. According to [8], wild fruits are essential for a balanced diet in humans, especially in children. [9] gives an overview of the importance of wild fruit trees in Gabon through a botanical description of several species of forest trees producing edible fruits of the family Anacardiaceae which are mainly packed with sweet fruits, acid to acidulous such as: Amvout Trichoscypha acuminata; T. abut; Pseudospondias longifolia; Onzabili Antrocaryon klaineana; Sorindea. There is considerable diversity of plant-based foods that can be grouped into species producing oleaginous substances and vegetable oils such as: Andok Irvingia 
gabonensis; Afo Poga oleosa; Afane Panda Oleosa; Moabi Baillonnella toxisperma as specified by [10]. In Gabon, [11] reports that Ovita seeds are frequently substituted for garlic, while Essesseng seeds are more often used as spices. He added that African expatriates, especially those from West Africa, use Monodora myristica as a Spices, while Gabonese people uses its medicinal properties.

The leaves $(36 \%)$ often prepared as vegetables, are also used as packaging. Gnetum africanum leaves are consumed by over $90 \%$ of households in south-western CAR, followed by Dorstenia spp. They are available in the markets throughout the year. The leaves of the species (Gnetum africanum) are well known to Central African populations. For [12] among the edible foliage of the humid forests of Central Africa and the DRC in particular, that of small lianas of the undergrowth of the genus Gnetum (belonging to the group of Gymnosperms, primitive order of the Gnetales with a single family (Gnetaceae), is particularly appreciated by the consumers who collect it. The genus Gnetum is the only genus present in the Gnetaceae family which includes about 30 species, mainly trees and shrubs from the tropical regions of Asia, from America and Africa (Martens, 1971 cited by $[13,14]$ showed in their studies that leaves $(38 \%)$ are consumed by the Congolese people. The leaves are finely cut, afterwards, consumed after cooking by the populations or sold on local markets. This is a species with a broad spectrum of distribution covering all of central Africa from Angola to Cameroon via Congo, Nigeria and Central African Republic [15].

In addition, the leaves of Marantaceae Megaphrynium macrostachyum are used by the households of the villages surveyed for various packaging of the products among which, the packaging of the chikwangue or stick of cassava (Magbéré en Sangô) and the "koko minced", not to mention caterpillars. These leaves are also used by indigenous people to cover the roof of their homes. These same uses have been observed in south-western CAR (Pissa, Mbaïki, Berberati, etc.) by several authors $[16,17]$. In the DRC, the leaves of Megaphrynium macrostachyum are used by the populations of the villages of Botsima, Bekumankake and Besoi located on the north-eastern edge of the Salonga National Park, for the preparation of the Chikwangue. In addition to cultivated vegetables (cassava leaves, sweet potatoes or amaranth), children sometimes collect wild edible leaves in the forest, which develop in abundance at certain times of the year [18].

Added to use of fruits and leaves, the exploitation of palm wine occupies a preponderant place in the villages concerned by our study. The method of extraction of sap from the top is very common; but it does not supply a large quantity of sap, and does not cause too much damage. [19], showed that in Cameroon, the sap extraction method of cutting or uprooting the stipe, "from the bottom up" method, causes a lot of damage to oil palm populations, unlike the method "from above". The same observations were revealed in southwestern CAR by [20]. and in Gabon by [21] in 2010. The sap extracted by the second method, although less appreciated than that obtained "from the top", is indeed more abundant.
The daily use of non-timber forest species providing food from NTFPs by local populations in the area of our study has led us to distinguish the priority EFNL from the others. A total of nine (09) NTFPs producing NTFPs have been considered as priorities by the populations of the area, Gnetum africanum, Dostenia psilumus, Raphia vinifera and Elais guinenses are given priority with a score of 5; while the other five, namely Irvingia wombulu, Xylopia aetiopica, Dioscorea liebrechtsiana, Dacryodes edulis and Cola spp have a score of 4 . This prioritization corroborates the data of the national review on NTFPs conducted by [22]. in which it has presented at the national level 8 EFNL providing priority food from NTFPs including Gnetum africanum, Dorstenia psilumus, Raphia vinifera and Elais guinenses with a score of 5. This clearly shows that these species have remained in this privileged position for nearly 10 years.

The exploitation of NTFPs has an impact on the sustainability of the resource and seems to be closely linked to several parameters, notably the mode of collection and the pressure exerted on the resource due to the high demand by the populations to meet their socio-economic needs. At the Land Use Type level (old secondary forest, young secondary forest, partly undisturbed secondary forest, oldgrowth fallow, young fallow, coffee plantation and swamp) defined in this study, the effect of pressure on the anthropic approach to the sustainability of NTFPs has been more noticeable through some unpleasant practices that call for improvements. These practices include: removal of tree bark by debarking, felling of trees (trees or shrubs: case of Jatropha curcas, Raphia ssp.) and uprooting of certain species, especially herbaceous plants (case of Chromolena odorata). The gradual decline of some forest species providing NTFPs explains an intense harvest rate and confirms a daily human presence within plant communities of NTFPs. This has led to a regression of floristic diversity within exploited plant communities [23].

Several researchers have made the same observations by pointing out that farmers destroy some plants in order to make their way to the raffia palms for tapping [24-27]. It is also worth noting the creation of roads by logging companies which consists of transporting logs from the stump to the park. This approach is characterized by the use of heavy equipment affecting the ecosystem in different ways.

All of these practices explain the decrease in the richness of the plant species observed in the plant communities of NTFPs exploited in south-western CAR, and more specifically in the area of our study. The main hypothesis of our study, which states that "human activities contribute to the sustainable management of NTFPs of plant origin in CAR" is therefore not verified. On the other hand, the results obtained in the context of this study show that the intensification of human activities is already a threat to the progressive disappearance of species in the plant communities by providing NTFPs of plant origin in southwestern CAR. 


\section{Conclusion}

The forest belt of south-western CAR abounds in a diversity of food-based NTFPs of plant origin that can satisfy many of the needs of rural populations namely: food, health care, handicrafts, etc. These products are available and pursued all year round by the people living in this area. The impact observed through this study shows that food-based NTFPs of plant origin are under increasing anthropogenic pressures that lead to dysfunctioning of the forest ecosystems and loss of biodiversity. The definition of a sustainable exploitation strategy for NTFPs based in particular on the consideration of these plant resources in the forest management plan and the capacity building of NTFP stakeholders on ecological and socio-economic harvesting techniques constitute reliable solutions for ensuring sustainable management of these resources in the face of climate change. In addition, future research in CAR should take into account useful plants that are threatened with extinction or are poorly understood. This will involve harvesting fertile samples, preparing herb samples, also harvesting seeds and multiplying them in the nursery, and testing cuttings of certain EFNLs. This material could be used through agroforestry introduction trials, which will make it possible to conserve in the long term the plant biodiversity of the forest zone of the South-West of the Central African Republic.

\section{References}

[1] Bahuchet S, 1992. In the Central African forest, the Pygmies Aka and Baka. Selaf, Paris, 640.

[2] Biloso A., \& J., Lejoly, 2006. Exploitation and market study of non-timber forest products in Kinshasa, Tropicultura, 24 (3) 183-188.

[3] Bonané M., 2003. Prospective non timber forest products study of the CAR, 3-6pp.

[4] Bonané M. 2002: Gnetum buchholzianum and Piper Guinense in Ngotto forest. The Flamboyant, No. 55, 4344.

[5] Bonou A, Adegbidi A, Sinsin B. 2008. Estimation of the economic value of non-timber forest products (NTFPs) of plant origin in the village of Sampéto (Banikoara commune). Notes from the Applied Ecology Laboratory, 3 (2) http://www.notesdecologie. j.refer.org/document.php?id=594.

[6] Borrini-Feyerabend G., Farwar T., Nguinguiri C. and Ndangang V., 2000. Participatory Resource Management, Organization Negotiation and Learning by Action. GTZ and IUCN, Heidelberg. 96 p.

[7] Bourobou-Bourobou H. and Posso P. (1995). An overview of the importance of wild fruit trees in northeastern Gabon. Nature and Fauna, 336p.

[8] Christy P., Jaffre R., Ntougou O., Wilks C. 2003. The Forest and the Wood Sector in Gabon - The Forest of Gabon at the Beginning of the Third Millennium. Multipress Gabon, 67pp.

[9] Dhetchuvi, M.M., and Lejoly, J., 1996: The food plants of the dense forest of Zaire north-east of Salonga National Park, pp. 301-314. In the Tropical Forest Feed, 301p.

[10] Essomba D J P., 2009. Participatory approach for the sustainable use of medicinal flora in the forest zone of South Cameroon: case of the terroir of Tya'assono (Ntem Valley), $36 \mathrm{pp}$.

[11] Evrard, C., 1968. Ecological research on the forest stand of the hydromorphic soil of the Congolese Central Basin, Sér. Scientif. Publ. INEAC, 110, 295 p.

[12] FAO, 1999. Non-timber forest products and income generation. Rome, FAO, $125 \mathrm{p}$.

[13] Gounot M., 1969. Methods of quantitative studies on vegetation. Masson, Paris. pp. 30-119.

[14] Konzi-sarambo, n. f, Sunday, Lamba, B., 2012. National Strategy and Plan for Non-Timber Forest Products in the Central African Republic, 43p.

[15] Lescuyer G. 2010. Economic importance of non-timber forest products in some villages in South Cameroon. Tropical Timber and Forests, 304 (2): 15-24.

[16] Loubelo E., 2012. Impact of non-timber forest products (NTFPs) on the household economy and food security: the case of the Republic of Congo. PhD Thesis, University Rennes 2, France. 260 p.

[17] Mbetid-Bessane E., 2005a: Characterization of the Shea Oil Market in the Central African Republic, Tropicultura, p. 141145 .

[18] Mbetid-Bessane E., 2005b: Commercialization of crawfish food in the Central African Republic, Tropicultura, pp3-5.

[19] Mialoundama, F., 1996. Nutritional and socioeconomic interest of the Gnetum genus in Central Africa. In: Tropical forest feeding, bio cultural interactions. UNESCO (1996). Pp295-300.

[20] Mukerji, K.G. Kumar, R. N; Singh, N. 1995. Studies on Indian coprophilous fungi: IV. Species of the genera Apiosordaria and Cercophora. Phytomorphologie. 45: 87-105.

[21] N'gassé G., 2010. National Journal of Non-Timber Forest Products: NWFP (RCA), 63p.

[22] Ngoye, A., 2010. Bibliographic Review of Non-Timber Forest Products (NTFPs): Case of Gabon, 59p.

[23] Roche P., 1998. Biodiversity dynamics and human action. ENV-SRAE report - 94233, Paris, France. 6 pp.

[24] Chatat M., Puig H. and Tiki Manga T. 1995. House gardens in the Central and Southern Provinces of Cameroon: description and use of a traditional agroforestry system. Journ. Agric. Trad. and Bota. Appl. Flight. xxxvii (2): 165-182.

[25] Toirambe B., 2005: Place of NWFPs in the sustainable management of the Luki Biosphere Reserve in R. DC. Final work. Gembloux: FUSAGx. 77P.

[26] Yembi P., 2000. Preliminary survey on non-timber forest products on the markets of Libreville (Gabon). In Non-Timber Forest Products in Central Africa: Current Research and Prospects for Conservation and Development. Edited by T. C. H. Sunderland, L. E. Clark and P. Vantomme, FAO, Rome, 247-251pp. 